\title{
Review \\ Ecosystem services of the Southern Ocean: trade-offs in decision-making
}

\author{
SUSIE M. GRANTt, SIMEON L. HILL*†, PHILIP N. TRATHAN and EUGENE J. MURPHY \\ British Antarctic Survey, NERC, High Cross, Madingley Road, Cambridge CB3 OET, UK \\ *Corresponding author: sih@bas.ac.uk \\ ${ }^{\dagger}$ Joint first authors
}

\begin{abstract}
Ecosystem services are the benefits that mankind obtains from natural ecosystems. Here we identify the key services provided by the Southern Ocean. These include provisioning of fishery products, nutrient cycling, climate regulation and the maintenance of biodiversity, with associated cultural and aesthetic benefits. Potential catch limits for Antarctic krill (Euphausia superba Dana) alone are equivalent to $11 \%$ of current global marine fisheries landings. We also examine the extent to which decision-making within the Antarctic Treaty System (ATS) considers trade-offs between ecosystem services, using the management of the Antarctic krill fishery as a case study. Management of this fishery considers a three-way trade-off between fisheries performance, the status of the krill stock and that of predator populations. However, there is a paucity of information on how well these components represent other ecosystem services that might be degraded as a result of fishing. There is also a lack of information on how beneficiaries value these ecosystem services. A formal ecosystem assessment would help to address these knowledge gaps. It could also help to harmonize decisionmaking across the ATS and promote global recognition of Southern Ocean ecosystem services by providing a standard inventory of the relevant ecosystem services and their value to beneficiaries.
\end{abstract}

Received 19 February 2013, accepted 6 April 2013, first published online 12 June 2013

Key words: Antarctic krill, Antarctic Treaty System, ecosystem assessment, ecosystem-based management, food security, management objectives

\section{Introduction}

"Ecosystem services" are the benefits that mankind obtains from natural ecosystems (Millennium Ecosystem Assessment 2005, Daily et al. 2009) including food, fresh water and the maintenance of an equable climate. Human activities put pressure on natural systems, and obtaining one benefit (such as fish for food) from an ecosystem may impact its ability to provide other benefits (such as supporting biodiversity). Organizations charged with managing human activities that impact ecosystems must therefore make trade-offs between the different benefits that ecosystems provide (McLeod \& Leslie 2009, Link 2010, Watters et al. in press).

Recent "ecosystem assessments" have attempted to collate information on the character, status, distribution and value of ecosystem services at global or regional scales (IPBES 2012). The objective of collating such information is to clarify how ecosystems, the achievement of social and economic goals and the intrinsic value of nature are interconnected (Ash et al. 2010). Such assessments attempt to translate the complexity of nature into functions that can be more readily understood by decision-makers and nonspecialists. Their authors suggest that this increases the transparency of trade-offs associated with decisions that may impact ecosystems (Carpenter et al. 2006, Beaumont et al. 2007, Fisher et al. 2009, UK NEA 2011).

The continent of Antarctica and the surrounding Southern Ocean have, to date, been under-represented in global ecosystem assessments (e.g. Millennium Ecosystem Assessment 2005, UNEP 2010, 2012) and have not been the subject of any detailed regional assessment. This continent and ocean (which we subsequently refer to as the Antarctic) cover $9.7 \%$ of the Earth's surface area and play significant roles in the functioning of the Earth system (Lumpkin \& Speer 2007, Mayewski et al. 2009). Their under-representation in ecosystem assessments potentially limits the information available for decision-making about regional and global activities that impact Antarctic ecosystems. It could also lead to underestimates of the consequences of change in Antarctic ecosystems and the global significance of the services they provide.

The governance system for the Antarctic comprises a set of international agreements known as the Antarctic Treaty System (ATS). These treaties imply that the management of activities that impact ecosystems should consider the associated trade-offs. For example, the Protocol on 


\section{Goals of ecosystem- based management}

\section{Principles of conservation stated in the Convention}

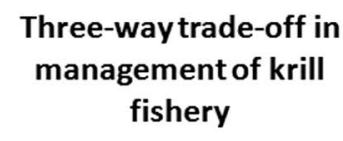

\section{Ecosystem services \\ (values/risks to be balanced) \\ balanced)}

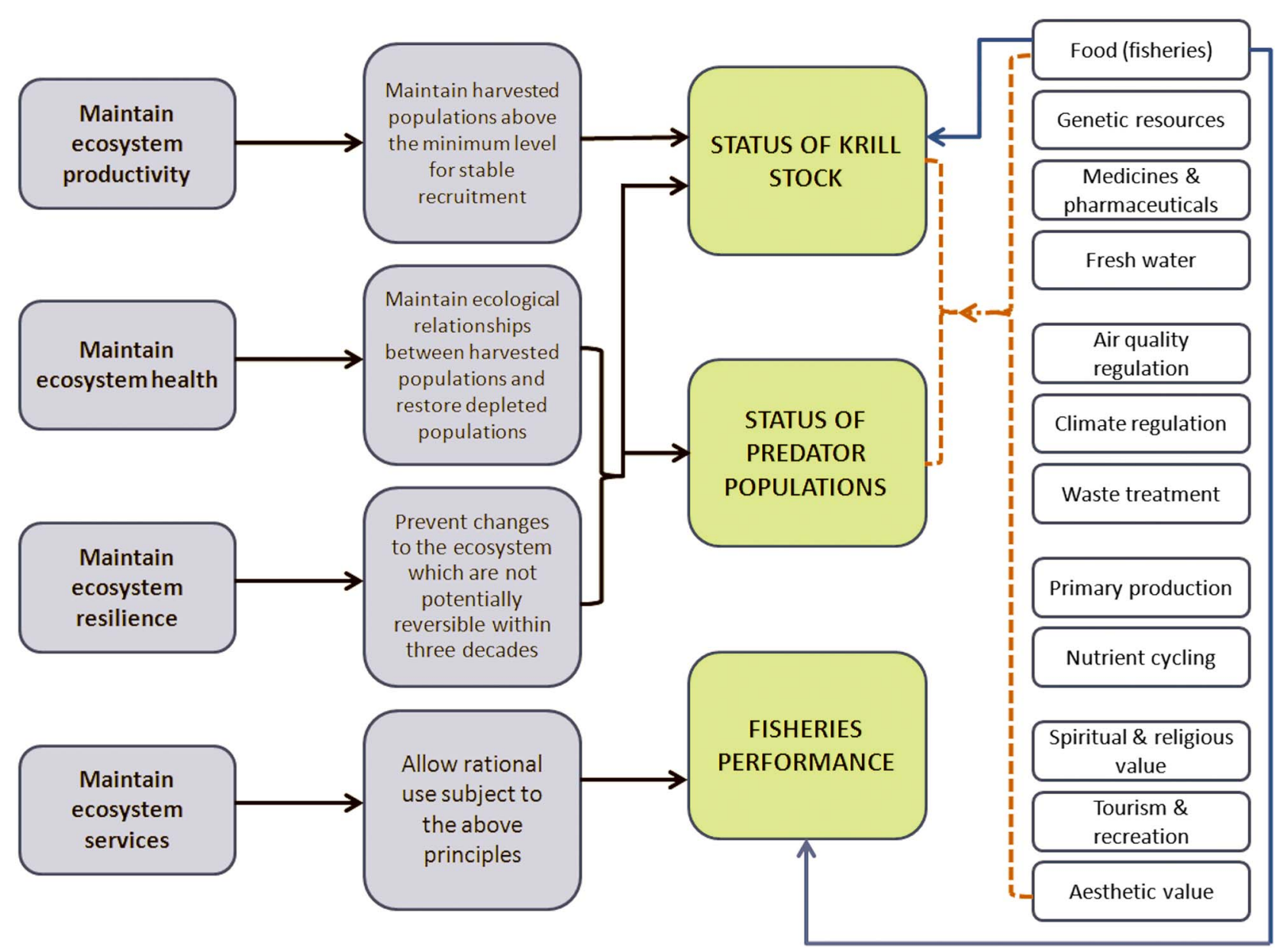

Fig. 1. The three-way trade-off used in krill fishery management and its relationship with conservation principles and ecosystem services. The goals of ecosystem-based management (McLeod et al. 2009) map directly onto the principles of conservation set out in the Convention (two left hand columns). The three-way trade-off (yellow boxes) is influenced primarily by the principles of conservation, and it explicitly considers maintenance of provisioning services (fishery catch) in the present (fishery performance) and in the future (status of the krill stock). It also considers the status of predator populations. Ideally krill fishery management should consider fishery impacts on all ecosystem services. The krill stock and predator populations are indicators of ecosystem health, but whether they are useful indicators of other ecosystem services (red lines) is unknown.

Environmental Protection (1991) recognized "the intrinsic value of Antarctica, including its wilderness and aesthetic values and its value as an area for the conduct of scientific research, in particular research essential to understanding the global environment" (http://www.ats.aq/documents/ recatt/Att006_e.pdf, accessed April 2013). Decisions on the conduct of human activities, including scientific research, must therefore consider potential impacts on environmental, aesthetic and wilderness values. The Convention on the Conservation of Antarctic Marine Living Resources underpins the management of fishing activities in the Southern Ocean. The Convention entered into force in 1982, and established the Commission for the Conservation of Antarctic Marine
Living Resources as its decision-making body. The acronym 'CCAMLR' is often used to refer to both the Convention and the Commission. In this paper, we use 'CCAMLR' to refer to the Commission and 'the Convention' to refer to the legal instrument. The Convention aims to ensure the "rational use" of marine living resources subject to "principles of conservation" (Fig. 1) including the maintenance of harvested stocks and of ecological relationships between harvested stocks and other species, the recovery of previously depleted stocks, and the prevention of irreversible change (http://www. ccamlr.org/en/document/publications/convention-conservationantarctic-marine-living-resources, accessed April 2013). Decisions that comply with the Convention must therefore 
consider the trade-offs between the current benefit of catches, the benefit of future catches from a healthy stock, and the more general benefits of a healthy ecosystem.

The purpose of the current paper is to review existing knowledge of Southern Ocean ecosystem services and the way this knowledge is currently used in decision-making. We collate available information on the identity, distribution, beneficiaries and global significance of Antarctic marine ecosystem services. We use the management of the main Southern Ocean fishery, which harvests Antarctic krill, Euphausia superba Dana, as a case study to explore the extent to which regional decision-making currently uses the type of information that formal ecosystem assessments generate. A full assessment of the status, trends and value of Southern Ocean ecosystem services is beyond the scope of this study, but we discuss the further work required and the potential benefits of conducting a formal ecosystem assessment. While we acknowledge that these objectives are also relevant to the terrestrial Antarctic, we limit our consideration to the marine ecosystem services of the Southern Ocean. For the purposes of this study, we define the Southern Ocean as the area covered by the Convention (http://www.ccamlr.org/ en/organisation/convention-area, accessed April 2013). The northern boundary of this area approximates to the position of the Antarctic Polar Front, which is an important ecological boundary between neighbouring oceans. This front is where cold polar surface waters sink beneath temperate surface waters. It is generally located between $c .50^{\circ} \mathrm{S}$ and $60^{\circ} \mathrm{S}$ (Moore et al. 1997); the higher latitude being the northern boundary of all other ATS agreements (http://www.ats.aq/imagenes/info/ antarctica_e.pdf, accessed April 2013).

The following two sections provide brief introductions to ecosystem assessment and direct human interactions with the Southern Ocean ecosystem. Tables I and II present key information about Southern Ocean ecosystem services, and the remaining sections consider the existing use of information on ecosystem services in the management of the Antarctic krill fishery in the Scotia Sea and southern Drake Passage. This forms the basis for our discussion of how an ecosystem assessment might aid CCAMLR's decision-making processes.

\section{Ecosystem assessment}

Ecosystem assessments aim to comprehensively characterize the status and trends of relevant ecosystems, the services they provide, the drivers of change, and the potential consequences of such change (Carpenter et al. 2006, Ash et al. 2010). This includes identifying how ecosystem services affect human well-being, who benefits, and where these beneficiaries are located. It can include identifying the specific value of ecosystem services to their beneficiaries (TEEB 2010). An ecosystem assessment adds value to existing information by clarifying how ecosystems, human well-being and the intrinsic value of nature are interconnected (UK NEA 2011). The practical purpose of these assessments is to provide information that can help decision-makers to better understand how their decisions might change specific ecosystem services. This theoretically equips decision-makers to choose policies that sustain the appropriate suite of services (Ash et al. 2010).

The Millennium Ecosystem Assessment (MA) was a landmark example of a global ecosystem assessment (Millennium Ecosystem Assessment 2005). Its objective was to "assess the consequences of ecosystem change for human well-being", and it established a framework which has formed the basis for a number of subsequent global and regional ecosystem assessments (e.g. CAFF 2010, UK NEA 2011, UNEP 2012). The MA recognized four categories of ecosystem services: provisioning (e.g. food, freshwater); regulating (e.g. climate regulation, water purification); cultural (e.g. aesthetic benefits and recreation); and supporting (e.g. nutrient cycling and primary production). These categories notably exclude the roles played by polar icecaps in storing water that would otherwise increase sea levels, and by sea ice in holding back continental ice and increasing the Earth's albedo. They also exclude some naturally occurring resources such as minerals and hydrocarbons.

The MA definition of ecosystem services includes benefits that are directly perceived and used by people (such as food and water) and those that are not (such as storm regulation by wetlands) (Costanza 2008). Direct-use benefits of ecosystem services may be consumptive (e.g. the consumption of wild caught fish), or non-consumptive (e.g. the enjoyment of those fish by scuba divers) (Saunders et al. 2010). Non-use benefits may be derived, for example, from the knowledge that a resource or service exists or is being maintained (Ledoux \& Turner 2002, Saunders et al. 2010). Benefits may be enjoyed at the location of a particular ecosystem service (e.g. local subsistence fishing) or at a great distance from it (e.g. large-scale commercial fishing by far seas fleets with global markets).

By definition, ecosystem services have value to their beneficiaries. Ecosystem assessments aim to identify the relative value of each ecosystem service based on various measures. In the case of consumptive use, it might be possible to measure value in economic terms, but it is also important to consider other types of value (Costanza et al. 1997). Various authors have described non-use benefits in terms of existence or presence value, altruistic value (knowledge of benefits being used by the current generation), and bequest value (knowledge of benefits being used by future generations) (Gilpin 2000, Chee et al. 2004, Saunders et al. 2010). The preservation of a resource or service for future use, or the avoidance of irreversible decisions until further information is available (Millennium Ecosystem Assessment 2005) is sometimes considered as a use value in itself (Saunders et al. 2010). However, it may be categorised separately as an unknown use, including a 
Table I. Summary of ecosystem services provided by the Southern Ocean. The "Ecosystem components" column identifies the ecosystem components that are critical to the provision of the relevant service.

\begin{tabular}{|c|c|c|c|}
\hline Ecosystem service & Description & Ecosystem components & Spatial distribution \\
\hline \multicolumn{4}{|l|}{ Provisioning services } \\
\hline \multirow[t]{6}{*}{ Fisheries products } & $\begin{array}{l}\text { Patagonian toothfish (Dissostichus eleginoides) and } \\
\text { Antarctic toothfish (D. mawsoni) sold mainly as high- } \\
\text { value fish for direct human consumption. }\end{array}$ & $\begin{array}{l}\text { Spawning areas in deep water and shallow } \\
\text { nursery habitats (Hanchet } \text { et al. 2008). } \\
\text { Ocean current systems - transport of larvae } \\
\text { and juveniles (Hanchet } \text { et al. 2008). } \\
\text { Production and availability of prey species } \\
\text { (e.g. notothenids, myctophids and krill) } \\
\text { (Collins } \text { et al. 2007). }\end{array}$ & $\begin{array}{l}\text { Continental shelf areas including South Georgia, } \\
\text { Heard Island \& McDonald Islands, Prince Edward } \\
\text { Islands, Ross Sea, Iles Kergulelen \& Iles Crozet } \\
\text { (SC-CAMLR 2012). }\end{array}$ \\
\hline & $\begin{array}{l}\text { Krill (Euphausia superba) used mainly in meal and } \\
\text { krill oil production and as the basis for various } \\
\text { biochemical products. }\end{array}$ & $\begin{array}{l}\text { Sea ice formation - winter/spring krill } \\
\text { habitat (Loeb et al. 1997). } \\
\text { Primary production - algae associated with } \\
\text { sea ice (winter) and phytoplankton blooms } \\
\text { (summer) (Atkinson et al. 2004). }\end{array}$ & $\begin{array}{l}\text { Highest krill abundances and majority of krill fishing } \\
\text { occurs in Scotia Sea and Southern Drake Passage } \\
\text { (CCAMLR Area 48) (Atkinson et al. 2004, } \\
\text { CCAMLR 2012a). }\end{array}$ \\
\hline & & $\begin{array}{l}\text { Ocean current systems - transport of krill in } \\
\text { ACC across the Scotia Sea (e.g. from spawning } \\
\text { sites along western Antarctic Peninsula to } \\
\text { South Georgia) (Murphy et al. 2004). }\end{array}$ & $\begin{array}{l}\text { 58.4.1 and 58.4.2 (East Antarctica), but there is no } \\
\text { current harvesting in this region (CCAMLR 2012a). }\end{array}$ \\
\hline & $\begin{array}{l}\text { Other species e.g. mackerel icefish (Champsocephalus } \\
\text { gunnari), rays (Raja spp.) and lithoid crabs (Paralomis } \\
\text { formosa). }\end{array}$ & $\begin{array}{l}\text { Spawning and nursery areas in appropriate } \\
\text { habitats. }\end{array}$ & $\begin{array}{l}\text { Demersal fish including mackerel icefish are harvested } \\
\text { from shallow island shelves while lithoid crabs and } \\
\text { rays are harvested from deeper waters. There are }\end{array}$ \\
\hline & & $\begin{array}{l}\text { Ocean current systems - transport of larvae } \\
\text { and juveniles. }\end{array}$ & $\begin{array}{l}\text { Conservation Measures for these species in subareas } \\
48.3 \text { and } 58.5 \text {. }\end{array}$ \\
\hline & & $\begin{array}{l}\text { Production and availability of prey species } \\
\text { (e.g. krill, copepods, myctophids, benthos). }\end{array}$ & \\
\hline Genetic resources & $\begin{array}{l}\text { Genetic diversity in all marine species, including } \\
\text { harvested resources. }\end{array}$ & $\begin{array}{l}\text { All ecosystem components supporting } \\
\text { biodiversity. }\end{array}$ & All Southern Ocean. \\
\hline $\begin{array}{l}\text { Biochemicals, medicines, } \\
\text { pharmaceuticals }\end{array}$ & $\begin{array}{l}\text { Bioprospecting for biological resources (plants, } \\
\text { animals, microorganisms) that can be used for } \\
\text { e.g. pharmaceutical or industrial products } \\
\text { (Jabour-Green \& Nicol 2003). }\end{array}$ & $\begin{array}{l}\text { All ecosystem components supporting } \\
\text { biodiversity. }\end{array}$ & Potentially all Southern Ocean. \\
\hline Fresh water & Fresh water stored in icebergs and ice shelves. & Formation of ice shelves and iceberg calving. & Coastal areas, ice shelves. \\
\hline \multicolumn{4}{|l|}{ Regulating services } \\
\hline Air quality regulation & $\begin{array}{l}\text { Uptake of chemicals and pollutants from the } \\
\text { atmosphere. }\end{array}$ & $\begin{array}{l}\text { Waste treatment, nutrient cycling, } \\
\text { sequestration of } \mathrm{CO}_{2} \text { (see below). }\end{array}$ & $\begin{array}{l}\text { All Southern Ocean, and storage of pollutants in } \\
\text { marine sediments. }\end{array}$ \\
\hline \multirow[t]{3}{*}{ Climate regulation } & $\begin{array}{l}\text { Antarctic Bottom Water as a driver of global ocean } \\
\text { circulation (Rintoul et al. 2001). }\end{array}$ & $\begin{array}{l}\text { Formation of Antarctic Bottom Water and } \\
\text { transport northwards (Orsi et al. 2001, } \\
\text { Rintoul } \text { et al. 2001). }\end{array}$ & $\begin{array}{l}\text { Formation over continental shelf and in polynyas; } \\
\text { transport in abyssal ocean (Orsi et al. 2001). }\end{array}$ \\
\hline & $\begin{array}{l}\text { Sequestration of } \mathrm{CO}_{2} \text { by the Southern Ocean } \\
\text { (Sabine et al. 2004, Le Quéré et al. 2007). }\end{array}$ & $\begin{array}{l}\text { Solution of } \mathrm{CO}_{2} \text { in seawater, and sinking of } \\
\text { dead organic matter (Sabine et al. 2004). }\end{array}$ & $\begin{array}{l}\text { All Southern Ocean. } \\
\text { Coastal areas, ice shelves. }\end{array}$ \\
\hline & Regulation of global sea level (Turner et al. 2009). & $\begin{array}{l}\text { Floating ice shelves may hold back further } \\
\text { melting of ice sheets on land. }\end{array}$ & \\
\hline Waste treatment & Decomposition of organic wastes. & $\begin{array}{l}\text { Decomposition by bacteria and } \\
\text { microorganisms. }\end{array}$ & All Southern Ocean. \\
\hline \multicolumn{4}{|l|}{ Supporting services } \\
\hline $\begin{array}{l}\text { Photosynthesis \& primary } \\
\text { production }\end{array}$ & $\begin{array}{l}\text { Photosynthesis by phytoplankton. } \\
\text { Assimilation of energy and nutrients by phytoplankton, } \\
\text { as a food source for higher trophic levels. }\end{array}$ & $\begin{array}{l}\text { Production of oxygen and uptake of } \mathrm{CO}_{2} \text { by } \\
\text { phytoplankton. } \\
\text { Summer phytoplankton blooms, growth of } \\
\text { winter sea ice algae. } \\
\text { Upwelling of nutrient-rich waters. }\end{array}$ & $\begin{array}{l}\text { Highly variable, but regions of high productivity } \\
\text { include Polar Frontal Zone and Marginal Ice Zone } \\
\text { (Treguer \& Jacques 1992). }\end{array}$ \\
\hline Nutrient cycling & $\begin{array}{l}\text { Cycling of nutrients required for plant production such } \\
\text { as nitrogen, phosphorus \& silicon (Knox 2007). }\end{array}$ & $\begin{array}{l}\text { Nitrogen fixation, microbial communities, } \\
\text { decomposition of organic wastes (Knox 2007). }\end{array}$ & All Southern Ocean. \\
\hline \multicolumn{4}{|l|}{ Cultural services } \\
\hline Spiritual \& religious value & $\begin{array}{l}\text { Spiritual and symbolic value of Antarctica as a } \\
\text { wilderness. }\end{array}$ & All ecosystem components. & All Southern Ocean. \\
\hline Tourism \& recreation & $\begin{array}{l}\text { Tourist cruises, yachts, scenic flights, adventure } \\
\text { tourism. }\end{array}$ & $\begin{array}{l}\text { Antarctic wildlife, particularly marine } \\
\text { mammals and birds. } \\
\text { Areas of particular aesthetic value. }\end{array}$ & $\begin{array}{l}\text { All Southern Ocean, particularly wildlife and scenery } \\
\text { in coastal regions. } \\
\text { Majority of tourist landings currently in Antarctic } \\
\text { Peninsula region, with smaller numbers visiting } \\
\text { sub-Antarctic islands and continental sites in } \\
\text { e.g. the Ross Sea region. }\end{array}$ \\
\hline Aesthetic value & Wilderness areas, wildlife, undisturbed spaces. & All ecosystem components. & $\begin{array}{l}\text { All Southern Ocean, particularly wildlife and scenery } \\
\text { in coastal regions. }\end{array}$ \\
\hline
\end{tabular}


Table I. Summary of ecosystem services provided by the Southern Ocean. The "Ecosystem components" column identifies the ecosystem components that are critical to the provision of the relevant service.

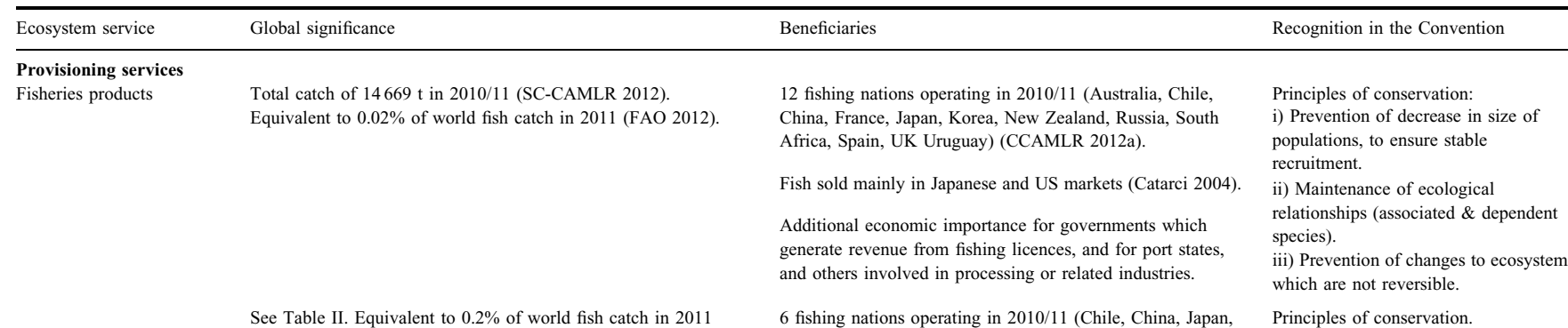

(FAO 2012).

The reported catch of species other than krill or toothfish was $2109 \mathrm{t}$ in 2010/11 (CCAMLR 2012a).

Genetic resources

Required for maintenance of Southern Ocean biodiversity, including harvested resources.

Biochemicals, medicines,

pharmaceuticals

Unknown future medical and economic value (Jabour-Green \& Nicol 2003)

Fresh water

Regulating services Air quality regulation

Climate regulation

Supporting services

Photosynthesis \& primary production

Nutrient cycling

Cultural services

Spiritual \& religious value

Unknown, but significant symbolic value to many people who have or have not visited the region.

Tourism \& recreation

33824 tourists visited Antarctica in 2010/11 season (www.iaato.org), in comparison to $87 \times 10^{6}$ visiting Florida in 2011 (www.visitflorida.com) (Antarctica is 80 times the size of Florida, but has only $0.04 \%$ of the number of Florida's visitors) source of freshwater for other regions.

Global ocean circulation system drives weather patterns and regulates temperature in all parts of the world. Increasing absorption may result in $\mathrm{CO}_{2}$ saturation limiting further tens of $\mathrm{cm}$ to global sea level by 2100 .

Projected total sea level rise of up to $1.4 \mathrm{~m}$ by 2100 (Turner et al. 2009).

Required for maintenance of Southern Ocean biodiversity.
Not currently used as a resource but has been proposed as a future Unknown

Uptake of $\mathrm{CO}_{2}$ and other pollutants contributes to global air quality.

Southern Ocean is one of the major global sinks of atmospheric $\mathrm{CO}_{2}$.

Global

Krill products sold primarily in US, Asian \& European markets (Nicol et al. 2012).

Additional economic importance for governments which generate revenue from fishing licences, and for port states and others involved in processing or related industries.

Unknown, but potentially global.

Unknown, but potentially global

Global

Global

Global

Global

Principles of conservation

rinciples of conservation

No specific recognition, although the principles of conservation require the maintenance of harvested, associated and dependent populations.

No specific recognition, although the principles of conservation require the maintenance of harvested, associated and dependent populations.

None

None

None

None

None

None

No specific recognition, although the principles of conservation require the maintenance of harvested, associated and dependent populations.

Global

Unknown, but potentially global.

Current cost of tourism limits potential beneficiaries to a very small minority of the global population.

IAATO members include 102 companies from 15 countrie (South America, North America, Europe, Japan, Australia and New Zealand) (www.iaato.org)

Additional economic importance for governments charging landing fees and "Antarctic gateway" ports.

Unknown, but potentially globa
No specific recognition, although the principles of conservation require the maintenance of harvested, associated and dependent populations.

No specific recognition, although the principles of conservation require the maintenance of harvested, associated and dependent populations.

No specific recognition, although the principles of conservation require the maintenance of harvested, associated and dependent populations. 
Table II. Comparative value of the current catch, catch limits, and standing stock estimates of Antarctic krill at two geographic scales. Values in bold are the results of our calculations, which include values based on market values of krill products and equivalent percentages of global marine capture fishery production (by mass). Other values are the assumptions on which these results are based and were obtained from the stated sources.

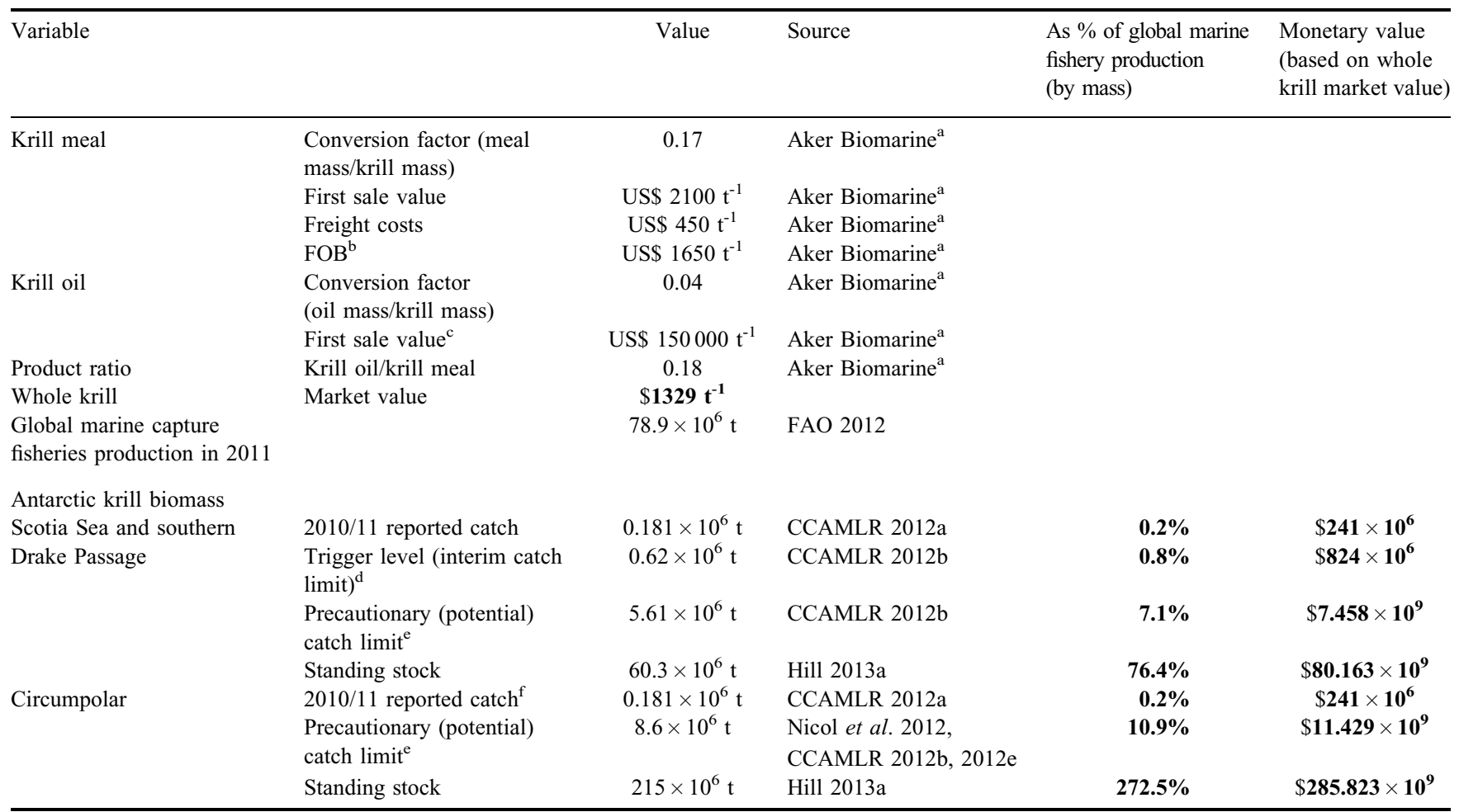

${ }^{a}$ Information supplied December 2011 by Aker Biomarine, a major krill fishing company.

${ }^{\mathrm{b}}$ Free on board value $(\mathrm{FOB})=$ market value minus freight costs.

${ }^{\mathrm{c}}$ First sale value for krill oil does not include production or freight costs.

dhe "trigger level" is the term used in Conservation Measure 51-01 (CCAMLR 2012b) to describe the currently operational catch limit. This limit is in place until a procedure for subdivision of the overall catch limit into smaller management units has been established. We have referred to this as the "interim catch limit" in the main text.

e The "precautionary catch limit" is the term used in Conservation Measures (CCAMLR 2012b, 2012c) to describe the total catch that could be permitted once spatial subdivision has been agreed.

${ }^{\mathrm{f}}$ Although there are catch limits for areas outside the Scotia Sea and southern Drake Passage, there were no reported catches for these areas in 2010/11.

'quasi-option value' where future use assumes the availability of increased knowledge or technology (Ledoux \& Turner 2002, Chee et al. 2004).

The objective of ecosystem assessment to provide a comparison between ecosystem services has led to attempts to express these different values in standardized, and often monetary, terms. The monetary value of an ecosystem service is arguably equivalent to the cost of replacing that service or finding another means of gaining similar benefits (Ledoux \& Turner 2002). In some cases, particularly for those services which constitute the Earth's life support systems (e.g. climate regulation) this value is unlimited, because the service would be irreplaceable if lost completely.

The Total Economic Value (TEV) framework is increasingly used to assess the value of ecosystem services by combining both monetary and non-monetary aspects of overall value (Ledoux \& Turner 2002). Figure 2 sets out a simple TEV framework adapted from previous studies (Ledoux \& Turner 2002, Chee et al. 2004, Saunders et al. 2010).
The loss of 'natural capital' such as forests or fish stocks is not included in traditional economic accounting models such as Gross Domestic Product (GDP) (Dasgupta 2010). In some cases, the exploitation of natural resources might result in a positive growth in GDP, when the degradation or unsustainable use of those resources has in fact reduced natural capital. Valuation of ecosystem services provides information that might help to inform policy decisions that reduce such loss or degradation of natural capital (Costanza et al. 1997, Ledoux \& Turner 2002).

\section{Human uses of the Southern Ocean}

The Southern Ocean is the only ocean that does not border a permanently inhabited landmass and, consequently, it was unknown and unexploited until the late 1700s. The economic importance of its ecological resources grew rapidly following Captain Cook's discovery of abundant fur seals at South Georgia in 1775. The Southern Ocean 


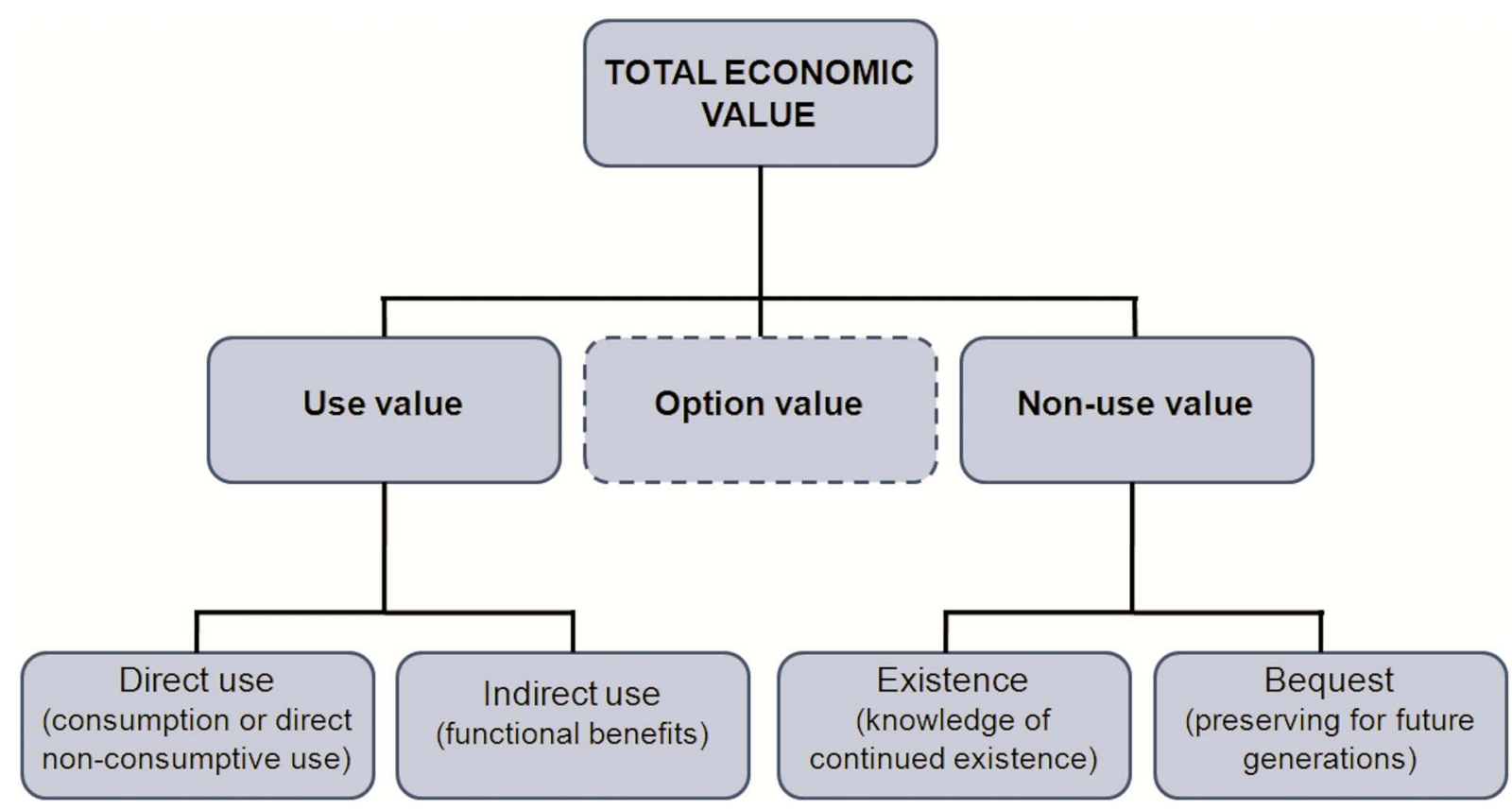

Fig. 2. The Total Economic Value (TEV) framework for valuation of ecosystem services (adapted from Ledoux \& Turner 2002, Chee et al. 2004, Saunders et al. 2010).

became the world's main source of seal products in the 1800s and whale products in the 1900s (Bonner 1984, Headland 1992). Populations of fur seals were reduced almost to extinction by the early 19th century. Attention then shifted to elephant seals and southern right whales. By the first half of the 20th century, these stocks had also declined and improved technology allowed offshore hunting of other baleen whales and sperm whales to become established. Whaling ceased in the 1960s when it was no longer economically viable. Finfish and then Antarctic krill became the major focus for exploitation, which continues until the present-day. Historical harvesting operations and catch sizes are mainly well documented (e.g. Laws 1953, Kock 1992, CCAMLR 2012a, Hill 2013a, fig 14.5), although illegal, unregulated and unreported (IUU) fishing has occurred, most recently for high-value toothfish (Österblom \& Bodin 2012). The extent and scale of this living resource extraction, and the fact that some whale and finfish stocks remain depleted (Bonner 1984, Kock 1992) demonstrates that the Southern Ocean is far from being a pristine wilderness as it is sometimes characterized.

The hostile and remote nature of the Southern Ocean, and the lack of a permanent human population have constrained direct use of its ecosystem services. Nevertheless, marine harvesting, science and tourism all directly impact the Antarctic environment (Clarke \& Harris 2003, Tin et al. 2009). Scientific research and its associated logistic and support requirements have been a major focus of human activities in Antarctica and the Southern Ocean since the early 20th century. Up to 6000 scientific and support personnel are stationed in and around Antarctica at the peak of the summer season (Clarke \& Harris 2003), and the Antarctic Treaty aims to maintain a high level of protection for the Antarctic environment as a scientific resource. The iconic wildlife, unique seascapes and coastlines, and relative isolation are all important factors in attracting recreational visitors. Antarctic tourism did not become established until the 1970s, and although it has expanded and diversified significantly during the last 40 years the number of visitors remains relatively low (around 35000 each year; http:// iaato.org/tourism-statistics, accessed April 2013).

\section{Ecosystem services provided by the Southern Ocean}

Using the four categories identified by the MA, we have identified and described the ecosystem services provided by the Southern Ocean and the ecosystem components corresponding to the provision of these services (Table I). Of the 24 ecosystem services examined by the MA we suggest that 12 have direct relevance in the Southern Ocean. Others are relevant only to terrestrial habitats or where there is a resident human population. Table I also lists the current beneficiaries of each identified ecosystem service and the spatial distribution of these services where applicable. Species that are particularly important to the provision of ecosystem services include harvested species such as Antarctic krill, toothfish, and other fish species; iconic or flagship species (Zacharias \& Roff 2001) such as penguins, whales, seals and albatrosses; and phytoplankton, zooplankton, and macro-zooplankton species which play 
key roles in primary production and nutrient cycling. There are potential benefits from services which are as yet unknown in the Southern Ocean. Endemism is high in many marine taxa (Arntz et al. 1997) suggesting the potential for products that cannot be sourced elsewhere. A few genetic and biochemical materials have been patented for use in pharmaceutical or industrial products but the potential of such resources has yet to be fulfilled (Jabour-Green \& Nicol 2003). Other services such as the provision of freshwater may not be viable or utilized at present, but remain potentially important for the future if there are changes to global supply and demand.

Ecosystem services provided by the Southern Ocean have few direct, local beneficiaries. The provisioning services support consumption elsewhere. For example, markets for toothfish and Antarctic krill products are predominantly in northern hemisphere nations in East Asia, North America, and Europe (Catarci 2004, Nicol et al. 2012). Regulating and supporting services such as climate regulation, ocean circulation and nutrient cycling provide benefits to human populations globally.

Marine ecosystem services may occur within welldefined locations (e.g. the spawning grounds of a particular fish species which support a provisioning service), or across much larger and spatially less distinct areas (e.g. sequestration of $\mathrm{CO}_{2}$ across the entire Southern Ocean). There is some potential for spatially explicit mapping of ecosystem services in the Southern Ocean, for example to illustrate the spatial dimension of catch value (UK NEA 2011). Information is also available on tourist landing sites (http://iaato.org/tourismstatistics) and ship traffic (Lynch et al. 2010). Mapping of regulating and supporting services may be more difficult to achieve, although datasets such as sea surface chlorophyll concentrations (e.g. http://oceancolor.gsfc.nasa.gov) may serve as useful proxies.

Table II presents some simple estimates of the comparative value of the Antarctic krill stock as an illustration of the value of Southern Ocean ecosystem services. The Antarctic krill stock in the Scotia Sea and southern Drake Passage is managed with an interim catch limit but there is also a higher potential limit, known as the "precautionary catch limit" (CCAMLR 2012b). These two catch limits are respectively equivalent to $0.8 \%$ and $7.1 \%$ of global marine capture fisheries production in 2011 (FAO 2012) with first sale values of about US\$ $824 \times 10^{6} \mathrm{yr}^{-1}$ and US\$ $7.4 \times 10^{9} \mathrm{yr}^{-1}$. The comparable first sale value of the global fish catch is $c$. US\$ $85 \times 10^{9} \mathrm{yr}^{-1}$ (Pikitch et al. 2012). The current market for krill oil alone is $c$. US\$ $82 \times 10^{6} \mathrm{yr}^{-1}$ (Hill 2013a). These economic values should be considered alongside the value of other ecosystem services provided by the Antarctic krill stock. Pikitch et al. (2012) estimated that the contribution to predator production made by Antarctic krill is higher than that of any comparable species in the world's oceans. Other types of value based on the components of TEV (Fig. 2) might include option, existence, or bequest value. Investment in research and conservation gives some indication of the importance society currently attaches to ecological resources. The coverage of closed or protected areas which limit fishery access, for example at the South Orkney Islands (CCAMLR 2012c) and South Georgia (http://www.sgisland.gs/download/MPA/ MPA\%20Plan\%20v1-1.01\%20Feb\%2027_12.pdf), is a nonmonetary indication of conservation investment. However, the cost of research and protection is likely to be much lower than the hypothetical replacement value.

\section{Existing use of information about ecosystem services in the ATS}

Ecosystem assessments aim to characterize ecosystem services in terms of their identity and status. This status might be assessed relative to reference points defining desirable states. Ecosystem assessments also attempt to identify the beneficiaries of ecosystem services and to evaluate potential drivers and consequences of future ecosystem change. This is intended to facilitate decisionmaking based on trade-offs between ecosystem services. This section uses the Antarctic krill fishery in the Scotia Sea and southern Drake Passage as a case study to identify the extent to which management processes consider tradeoffs and use the types of information that are collated in ecosystem assessments.

\section{Overview of decision making within CCAMLR}

The instruments of the ATS govern existing and potential human activities in the Southern Ocean, although these instruments are legally binding only on signatory nations. The Protocol on Environmental Protection prohibits mineral exploitation south of $60^{\circ} \mathrm{S}$ and specifies the conduct of scientific, logistic and tourist operations. CCAMLR manages fishing activities in the wider Southern Ocean ecosystem. A total of $8 \%$ of this area falls under the jurisdiction of national governments (including the marine areas around Heard Island and McDonald Island, Iles Kerguelen and Iles Crozet, the Prince Edward Islands, South Georgia and the South Sandwich Islands), some of which apply CCAMLR management measures.

CCAMLR manages fishing and related activities by implementing regulations known as Conservation Measures. Commissioners are representatives of national governments. CCAMLR is advised by a Scientific Committee which, in turn, is advised by a number of scientific working groups. Decision-making at each of these levels is by consensus (Hill 2013a, fig 14.4).

The Antarctic krill fishery in the Scotia Sea and southern Drake Passage accounted for $91 \%$ by mass of the total Southern Ocean catch in the 2010-11 fishing season (CCAMLR 2012a). There are a number of reviews that describe the development of CCAMLR's management 
approach for this fishery (Constable et al. 2000, Miller \& Agnew 2000, Hill 2013a), which we also summarize here.

The Convention's principles of conservation (CCAMLR 1982) were an early articulation of the goals of Ecosystem Based Management. Ecosystem Based Management takes account of trade-offs between ecosystem services, and has the goals of maintaining the ecosystem productivity, health and resilience that underpins the provision of ecosystem services (McLeod \& Leslie 2009). Management of Antarctic krill fisheries has generally focused on the three-way trade-off between the performance of the fishery, the status of the krill stock, and the status of selected krill predators. In this tradeoff, the status of krill predators is used as a proxy for the health and resilience of the wider ecosystem (Fig. 1), although CCAMLR has also considered other impacts of the fishery, such as larval fish bycatch (Agnew et al. 2010).

The Antarctic krill harvest from the Scotia Sea and southern Drake Passage has been capped at $620000 \mathrm{t} \mathrm{yr}^{-1}$ since CCAMLR first began to regulate the fishery in 1991. This interim catch limit is less than the "precautionary

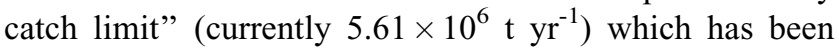
updated a number of times in response to revised estimates of Antarctic krill biomass (e.g. Trathan et al. 1995, Hewitt et al. 2004a, SC-CAMLR 2010). The "precautionary catch limit" defines the potential maximum harvest when the management approach is sufficiently developed to allow the interim limit to be removed.

CCAMLR's scientific working groups have used the three-way trade-off to develop and evaluate management approaches that address two key questions: what is the appropriate overall catch limit, and how should this be spatially distributed to minimize local depletion of krill and its predators? The first question led to a set of decision rules which CCAMLR established in the early 1990s to identify the "precautionary catch limit" (SC-CAMLR 1994). These decision rules were formulated for use with simulation models and an estimate of the initial biomass of Antarctic krill, which is assumed to represent the biomass prior to any impacts of fishing. One rule allows for the simulated Antarctic krill stock to be depleted to $75 \%$ of its initial biomass. This compares with the maximum sustainable yield reference point which is widely used in other fisheries and allows depletion to around 60\% (Smith et al. 2011). Thus the decision rule reserves a proportion of Antarctic krill production for its predators. Smith et al. (2011) suggested that depletion to $75 \%$ of initial biomass represents a reasonable trade-off between the benefits of harvesting and ecosystem health. Another rule constrains the risk of the simulated krill population falling to low levels likely to impact productivity.

Work is ongoing within CCAMLR's scientific working groups to address the second question. These groups have identified ecologically-based spatial subdivisions of the fishery (Hewitt et al. 2004b) and assessed the potential consequences of different spatial fishing patterns
(Plagányi \& Butterworth 2012, Hill 2013b, Watters et al. in press). The krill biomass in any area varies naturally over time (Brierley et al. 2002, Atkinson et al. 2004). The patterns of variability are also likely to change in response to climate change and fishing (Everson et al. 1992). It might therefore be appropriate to vary area-specific catch limits, or other activities, such as monitoring, in response to information about the state of the krill stock or the wider ecosystem (Constable 2002, Trathan \& Agnew 2010, SC-CAMLR 2011). CCAMLR's scientific working groups aim to develop a "feedback management procedure" (SC-CAMLR 2011) to address these issues. They have considered the use of data from the fishery, small-scale krill surveys (e.g. Brierley et al. 2002) and krill predators (Constable 2002, Hill et al. 2010) to indicate the state of the ecosystem. However, further work is required on all aspects of the proposed procedure, including definition of its specific objectives.

CCAMLR has not, to date, agreed a management approach that will prevent excessive localized depletion of the krill stock, and consequent impacts on krill predators, if catches increase beyond the interim catch limit. It therefore retains the interim limit and has recently established additional caps within the fishery's four subareas (CCAMLR 2012d).

The Antarctic krill catch increased from $126000 \mathrm{t}$ in 2001/02 to $181000 \mathrm{t}$ in $2010 / 11$. This expansion coincided with new developments in harvesting and processing technology and new markets for krill products (Nicol et al. 2012, CCAMLR 2012a). Catches remain below $0.4 \%$ of the estimated available biomass in the Scotia Sea and southern Drake Passage $\left(60.3 \times 10^{6} \mathrm{t}\right)$, while the interim catch limit is around $1 \%$ of this estimate. These values are low compared with most established fisheries elsewhere in the world (FAO 2012) and compared to the standard reference points used to evaluate sustainability (Worm et al. 2009) but some authors have questioned whether any krill fishing is sustainable (Jacquet et al. 2010).

The decision rules represent a practical solution to the need to balance effects on different ecosystem components, which did not require an economic valuation of the relevant ecosystem services. However, CCAMLR has not yet identified an approach which balances these effects at the appropriate ecological scale, and so relies on interim management measures. The current challenges facing the managers of the krill fishery include increasing demand for krill products, public interest in other ecosystem services that krill may support, and the pressure of climate change. CCAMLR is attempting to meet these challenges through developing a "feedback management procedure".

\section{Consideration of the character and status of ecosystem services}

Antarctic krill is an important species in much of the Southern Ocean, where it is a major prey item for a diverse community of predators including fish, seabirds, marine 
mammals and cephalopods (Atkinson et al. 2009, Hill et al. 2012). Ecosystem components of interest to CCAMLR therefore include the Antarctic krill stock and its predators. CCAMLR and the wider research community are actively addressing questions about the status and trends of these components. CCAMLR's ecosystem monitoring programme (CEMP) was established in 1987. It aims to detect and record significant changes in critical components of the marine ecosystem and to distinguish between changes due to harvesting of commercial species and changes due to environmental variability, both physical and biological (Croxall 2006). CEMP monitors Antarctic krill and nine predator species (penguins, albatrosses and fur seals) representing the 'dependent and related populations' referred to in the Convention's principles of conservation (Fig. 1). The monitored ecosystem components are consistent with the three-way trade-off. The choice of monitored components therefore reinforces the assumption that krill predators are suitable indicators of the wider state of the ecosystem. The spatial scales and species for which the state of predator populations should be evaluated to inform krill fishery management remain to be defined.

In 2000, CCAMLR conducted a multi-national largescale synoptic survey to estimate the biomass of Antarctic krill in $2 \times 10^{6} \mathrm{~km}^{2}$ of the Scotia Sea and southern Drake Passage (Hewitt et al. 2004a). Some CCAMLR Members also monitor krill biomass in smaller areas. For example, the UK has estimated biomass in an area of at least $8000 \mathrm{~km}^{2}$ to the north of South Georgia since 1981 and on a regular basis since 1996 (Brierley et al. 2002). A series of studies that integrate data from national science programmes has, independently of CCAMLR, produced recent estimates of circumpolar krill biomass and production, and an assessment of trends in krill abundance (Atkinson et al. 2004, 2009). Other studies, mainly associated with CEMP data, have assessed the status and trends of various krill predator populations (e.g. Forcada et al. 2005, Forcada \& Trathan 2009). Turner et al.'s (2009) review of Antarctic climate change and environment collated much of the relevant information from published scientific studies, while Flores et al. (2012) provided a more krill-focused review.

Many national science programmes and several international science coordination and implementation bodies have a Southern Ocean focus, addressing questions about the status and trends of ecosystems (e.g. Murphy et al. 2012). These programmes have sometimes identified a particular ecosystem service, or the need to manage activities that affect ecosystem services, as the motivation or benefit of their research, but none has aimed to provide a comprehensive assessment of ecosystem status and trends.

Definitions of the desirable states of ecosystem components and of the fishery (and therefore undesirable states to avoid) remain elusive (Hill 2013b). Two prominent recent studies have suggested tentative reference points for "forage" species, such as krill, that support diverse predators.
Cury et al. (2011) analysed the relationship between prey availability and seabird breeding success. They recommended maintaining forage species above a third of the maximum biomass observed in long-term studies. Smith et al. (2011) used ecosystem models to assess the propagation of fishery impacts through the foodweb. They suggested maintaining forage species above $75 \%$ of their unexploited biomass. Each of these reference points carries caveats which will need to be addressed before implementation. The Cury et al. (2011) analysis was based on aggregated data from a range of ecosystems, including the Scotia Sea. Simplistic application of its recommendations to the krill fishery suggests that krill should be maintained at levels which were only observed in six of the 21 years analysed. This highlights the difficulties in practical application of universal reference points. More detailed consideration of the scale of predator foraging, the response of different predators, and the current state of the ecosystem will be necessary to develop recommendations for the krill fishery. The $75 \%$ reference point has already been used to suggest overall krill catch limits, but CCAMLR recognizes that by itself this does not provide adequate protection against localized depletion of krill and consequent impacts on predators (Hewitt et al. 2004b).

\section{Consideration of beneficiaries of ecosystem services}

The Preamble to the Antarctic Treaty (1959) recognized that peaceful use of the Antarctic and scientific cooperation are in the interests of "all mankind" (http://www.ats.aq/ documents/ats/treaty_original.pdf, accessed April 2013). The Convention states a commitment to "rational use", which is often interpreted by CCAMLR Members as meaning sustainable fishing. However, the Convention does not explicitly define the term, meaning that it can be applied to the use of other ecosystem services (Watters et al. in press).

Questions about the ability of ecosystem services to supply local needs are inappropriate for the Southern Ocean due to the geographical separation between these ecosystem services and their beneficiaries. This fact might partly explain why there has been little direct consideration within CCAMLR of the relationships between ecosystem services and human well being.

The fishing industry and its employees, suppliers and customers are direct beneficiaries of the Antarctic krill fishery. The beneficiaries of other ecosystem services that the fishery could impact are less clearly defined, although these could include tourists, scientists, and others who might benefit from the maintenance of predator populations and the wider ecosystem (see Table I). The consensus decision-making in CCAMLR provides a mechanism for accommodating multiple opinions representing multiple ways of valuing different ecosystem services. However, consensus decision-making also has recognized drawbacks including the disproportionate influence of minority 
opinions and a tendency to default to the status quo. For many Members there will be pressure to ensure that decisions are defensible in terms of both the Convention and public opinion. Nonetheless, in order to have an influence, opinions must be represented at national government level, and there is no automatic requirement to represent all beneficiaries, or to consider the relative value of different ecosystem services to different beneficiaries.

Several conservation-focused non-governmental organisations (NGOs) also take an interest in krill fishery issues. Some of these have observer status within CCAMLR under the umbrella of the Antarctic and Southern Ocean Coalition. However, few interest groups or direct beneficiaries have stated their specific objectives for krill fishery management. Hill (2013a) noted that most groups identify "sustainability" as a key requirement but that few have provided a tangible definition of this term. Furthermore, some uses of this term are mutually contradictory. Nonetheless, Österblom \& Bodin (2012) reported that 117 diverse organizations responded to the crisis of IUU harvesting of toothfish in the Southern Ocean with shared purpose. Their actions resulted in a substantial reduction in IUU fishing. This suggests that effective cooperation between diverse interest groups is possible.

CCAMLR faces the challenge of making operational decisions on the basis of its conservation principles that are acceptable to a diverse community of beneficiaries and interest groups. At present there is little information about the values that these groups place on ecosystem services, or their specific objectives for the ecosystem or the fishery. The types of question posed by ecosystem assessments might help to identify these values and objectives.

\section{Consideration of future change}

The MA examined how ecosystems and the services they provide might change under plausible future scenarios. This is a key question being asked by many Antarctic-focused national science programmes and international coordinating bodies including the Scientific Committee on Antarctic Research and the Integrating Climate and Ecosystem Dynamics in the Southern Ocean programme (Murphy et al. 2012), in conjunction with ATS bodies including CCAMLR. The Intergovernmental Panel on Climate Change intends to increase its coverage of the status and prognosis for Southern Ocean ecosystems with a dedicated chapter in the forthcoming Fifth Assessment Report. The impetus for such activity has come mainly from the scientific community but the strong interaction between scientists and decision makers within CCAMLR ensures shared purpose.

The paucity of historical data presents a particular challenge for defining baseline status and relative reference points for living components of the Southern Ocean ecosystem (Hill et al. 2006, Trathan et al. 2012). Clarke \& Harris (2003) and Turner et al. (2009) identified key influences on the current status of Antarctic ecosystems, and suggest potential ecosystem responses to further change. Climate forcing is a major influence on the Southern Ocean ecosystem (Everson et al. 1992, Turner et al. 2009). This apparently results from complex interactions between natural climate processes, and the anthropogenic effects of the ozone hole and greenhouse gases (Turner et al. 2009, Turner \& Overland 2009). Although limited human activity in the Southern Ocean constrains the potential direct influences (Trathan \& Agnew 2010), potentially important drivers of change include: fishing; the ongoing consequences of historical exploitation of seals, whales and fish; pollution; disease; and invasive species (Clarke \& Harris 2003, Trathan \& Reid 2009).

The Convention identifies the importance of the effects of fishing and associated activities "on the marine ecosystem and of the effects of environmental changes". CCAMLR's 2009 resolution 30/XXVIII (http://www.ccamlr. org/en/resolution-30/xxviii-2009, accessed April 2013) also recognized the importance of climate change, urging "increased consideration of climate change impacts in the Southern Ocean to better inform CCAMLR management decisions" and encouraging "an effective global response to address the challenge of climate change". These statements require ongoing consideration of how to secure the delivery of a limited set of ecosystem services while minimizing the impact on others. Further work remains necessary to quantify and forecast environmental change, to understand levels of uncertainty, and to assess potential impacts on ecosystem services, including their social and economic implications.

\section{Discussion}

The previous sections have provided a preliminary characterization of the Southern Ocean's ecosystem services, demonstrating their global importance in terms of climate regulation, food supply and the maintenance of biodiversity. The high estimated value of the Antarctic krill stock relative to global fishery landings provides an illustration of this global significance. We have also discussed the extent to which the functions of ecosystem assessment are already integrated into the management of the Antarctic krill fishery. This demonstrates that trade-offs between the benefits obtained from harvesting and the potential impacts on other ecosystem services are a major component of CCAMLR's decision-making process.

The governance system for the Southern Ocean offers unique opportunities for managing the trade-offs between ecosystem services because its influence covers a whole ocean ecosystem. In 2009, CCAMLR designated a Marine Protected Area located entirely within the High Seas (CCAMLR 2012c). This global first is an important milestone in protecting ecosystems that are beyond national jurisdiction. Furthermore the Convention's principles of conservation effectively require management that accounts 
for such trade-offs. The developing management of the Antarctic krill fishery acknowledges these trade-offs, but simplifies them to a three-way consideration of fishery performance and the status of krill and predator populations. It is appropriate to assess whether this threeway trade-off fully represents CCAMLR's responsibilities under the Convention and the wider ATS. CCAMLR faces further challenges in developing its management approach, and in ensuring that this approach is co-ordinated with organizations responsible for other human activities at both the global and regional scale.

The ecosystem services of the Southern Ocean are a global resource from which all of mankind indirectly benefits. Most beneficiaries of these ecosystem services never have any direct contact with the ecosystem. There is, however, a small and relatively privileged group of direct beneficiaries that includes fishing and tourism companies, affluent tourists and consumers of the premium products (such as krill oil and Antarctic toothfish) derived from Antarctic fisheries. These activities also create employment and therefore another category of beneficiary. In their consideration of growing demand for marine fisheries products, Garcia \& Rosenburg (2010) identified krill as a resource that could perhaps support further exploitation. Thus, the composition of the group of direct beneficiaries could change over time. The spatial disconnect between the ecosystem services and the majority of beneficiaries means that the role of interest groups as intermediaries between beneficiaries and managers is particularly pronounced. There is an important distinction between beneficiaries and interest groups. Beneficiaries include the whole human race benefiting from a wide range of ecosystem services, while interest groups often focus on a narrow set of benefits and objectives. The specific requirements of beneficiaries are not currently well understood with the consequence that CCAMLR is yet to define operational objectives for the state of the krill stock, its predators and the wider ecosystem (Hill 2013a, 2013b, Watters et al. in press).

The Southern Ocean ecosystem is strongly influenced by human activities elsewhere (Clarke \& Harris 2003), and is particularly vulnerable to the effects of climate change (Turner et al. 2009). Ecosystem managers arguably have a duty to maintain the regulatory and supporting services required for healthy ecosystems, and therefore to ensure appropriate interaction with the wider global community on such issues. Identifying objectives that are consistent with its responsibility and influence are an additional challenge faced by CCAMLR.

Ecosystem assessment could help CCAMLR to meet these various challenges by providing a comprehensive characterization of the status, trends, and drivers of change to ecosystems and the services they provide for human well-being. A regional ecosystem assessment for the Southern Ocean would address its under-representation in existing global assessments. Such an assessment would also have benefits for CCAMLR and the wider ATS. Firstly, it would increase knowledge about the connections between the broad suite of Southern Ocean ecosystem services and the social and economic goals of CCAMLR Members. Clearer information on the value of ecosystem services would address the existing need for information about the objectives for each component of the three-way trade-off. It would also promote consideration of ecosystem services that are not currently represented in decision-making. Secondly, an assessment which gives equal consideration to the full range of provisioning, supporting, regulating and cultural services would be a substantial undertaking involving a wide community. This, in itself, could help forge more substantial links between the different components of the ATS. The end product would provide a consistent basis for coordinating activities related to managing or understanding ecosystem impacts.

The information presented here could provide a starting point for such an assessment. New research would be needed to fill some obvious gaps such as the spatial mapping (e.g. Naidoo et al. 2008, Maes et al. 2011) and economic valuation (e.g. Costanza et al. 1997) of ecosystem services, and the assessment would serve as a gap analysis to highlight other data needs. Best-practice developed in many other regional assessments could be useful (Ash 2010). CCAMLR is a user of information on the status and trends of marine ecosystems but it does not fund or directly mandate the collection of such data. The reliance of CCAMLR on donated information is a significant challenge to both the achievement of an ecosystem assessment and the long-term management of ecosystem services in the Southern Ocean (Hill 2013a, 2013b). There are several potential solutions, including a new initiative by the fishing industry to support the scientific work of CCAMLR (Nicol et al. 2012). We acknowledge that an ecosystem assessment would be a significant task in terms of resource requirements and coordination effort, but we believe it would deliver significant and long-term practical benefits.

\section{Conclusion}

The ecosystem services provided by the Southern Ocean are significant on a global scale, as illustrated by the potential of Antarctic krill to supply the equivalent of $11 \%$ of current world fishery landings. The terms "ecosystem services" and "ecosystem assessment" are not commonly used within the community concerned with managing human activities in the Southern Ocean. Nonetheless this community is actively gathering and applying much of the information that ecosystem assessments seek to collate. The Convention, in particular, articulates the requirement to consider trade-offs between ecosystem services. The management of the krill fishery represents a practical implementation of this requirement despite a lack of 
information about how beneficiaries value the relevant ecosystem services. A formal ecosystem assessment could provide necessary information on the wider suite of ecosystem services that fishing might interact with and how beneficiaries value these services. Such information is likely to aid the future development of krill fishery management and help remove the current reliance on interim measures. Formal and comprehensive ecosystem assessment would require considerable investment but could substantially improve coordination between management bodies focused on different human activities at both the regional and global scale.

\section{Acknowledgements}

This paper is a contribution to the Natural Environment Research Council core-funded British Antarctic Survey Ecosystems programme. We are grateful to Sigve Nordum of Aker Biomarine for supplying some of the information presented in Table II.

\section{References}

Agnew, D.J., Grove, P., Peatman, T., Burn, R. \& Edwards, C.T.T. 2010. Estimating optimal observer coverage in the Antarctic krill fishery. CCAMLR Science, 17, 139-154.

ARntZ, W.E., Gutt, J. \& Klages, M. 1997. Antarctic marine biodiversity: an overview. In Battaglia, B., Valencia, J. \& Walton, D.W.H., eds. Antarctic communities: species, structure and survival. Cambridge: Cambridge University Press, 3-14.

Atrinson, A., Siegel, V., Pakhomov, E.A., Jessopp, M.J. \& Loeb, V. 2009. A re-appraisal of the total biomass and annual production of Antarctic krill. Deep-Sea Research I, 56, 727-740.

Atrinson, A., Siegel, V., Pakhomov, E. \& Rothery, P. 2004. Long-term decline in krill stock and increase in salps within the Southern Ocean. Nature, 432, 100-103.

Ash, N., Blanco, H., Brown, C., Garcia, K., Henrichs, T., Lucas, N., Raudsepp-Hearne, C., Simpson, R.D., Scholes, R., Tomich, T.P., Vira, B. \& ZUREK, M. 2010. Ecosystems and human well-being: a manual for assessment practitioners. Washington DC: Island Press, 285 pp.

Beaumont, N.J., Austen, M.C., Atkins, J.P., Burdon, D., Degraer, S., Dentinho, T.P., Derous, S., Holm, P., Horton, T., van Ierland, E., Marboe, A.H., Starkey, D.J., Townsend, M. \& Zarzycki, T. 2007. Identification, definition and quantification of goods and services provided by marine biodiversity: implications for the ecosystem approach. Marine Pollution Bulletin, 54, 253-265.

Bonner, W.N. 1984. Conservation in the Antarctic. In Laws, R.M., ed. Antarctic ecology. Vol. II. London: Academic Press, 821-847.

Brierley, A.S., Goss, C., Grant, S.A., Watkins, J.L., Reid, K., Belchier, M. \& RoBst, J. 2002. Significant intra-annual variability in krill distribution and abundance at South Georgia revealed by multiple acoustic surveys during 2000/01. CCAMLR Science, 9, 71-82.

CAFF (Conservation of Arctic Flora and Fauna). 2010. Arctic biodiversity trends 2010 - selected indicators of change. Akureyri: Conservation of Arctic Flora and Fauna International Secretariat, 124 pp.

Carpenter, S.R., De Fries, R., Dietz, T., Mooney, H.A., Polasky, S., Reid, W.V. \& Scholes, R.J. 2006. Millennium ecosystem assessment: research needs. Science, 314, 257-258.

CATARCI, C. 2004. World markets and industry of selected commerciallyexploited aquatic species with an international conservation profile. FAO Fisheries Circular, No. 990. Rome: Food and Agriculture Organization, $186 \mathrm{pp}$.
CCAMLR (Commission for the Conservation of Antarctic Marine Living Resources). 2012a. Statistical Bulletin Volume 24 (2002-2011). Hobart, Australia: CCAMLR, 302 pp.

CCAMLR. 2012b. Conservation Measure 51-01 (2010). Schedule of conservation measures in force 2012/13. Hobart, Australia: CCAMLR. http://www.ccamlr.org/en/conservation-and-management/ browse-conservation-measures.

CCAMLR. 2012c. Conservation Measure 91-03 (2009). Schedule of conservation measures in force 2012/13. Hobart, Australia: CCAMLR. http://www.ccamlr.org/en/conservation-and-management/ browse-conservation-measures.

CCAMLR. 2012d. Conservation Measure 51-07 (2011). Schedule of conservation measures in force 2012/13. Hobart, Australia: CCAMLR. http://www.ccamlr.org/en/conservation-and-management/ browse-conservation-measures.

CCAMLR. 2012e. Conservation Measure 51-02 (2008). Schedule of conservation measures in force 2012/13. Hobart, Australia: CCAMLR. http://www.ccamlr.org/en/conservation-and-management/ browse-conservation-measures.

CHEE, Y.E. 2004. An ecological perspective on the valuation of ecosystem services. Biological Conservation, 120, 549-565.

Clarke, A. \& Harris, C.M. 2003. Polar marine ecosystems: major threats and future change. Environmental Conservation, 30, 1-25.

Collins, M.A., Ross, K.A., Belchier, M. \& Reid, K. 2007. Distribution and diet of juvenile Patagonian toothfish on the South Georgia and Shag Rocks shelves (Southern Ocean). Marine Biology, 152, 135-147.

Constable, A.J. 2002. CCAMLR ecosystem monitoring and management: future work. CCAMLR Science, 9, 233-253.

Constable, A.J., De la Mare, W.K., Agnew, D.J., Everson, I. \& Miller, D. 2000. Managing fisheries to conserve the Antarctic marine ecosystem: practical implementation of the Convention on the Conservation of Antarctic Marine Living Resources (CCAMLR). ICES Journal of Marine Science, 57, 778-791.

Costanza, R. 2008. Ecosystem services: multiple classification systems are needed. Biological Conservation, 141, 350-352.

Costanza, R., D’Arge, R., De Groot, R., Farber, S., Grasso, M., Hannon, B., Limburg, K., Naeem, S., O’Neill, R.V., Paruelo, J., Raskin, R.G., Sutton, P. \& van den Belt, M. 1997. The value of the world's ecosystem services and natural capital. Nature, 387, 253-260.

Croxall, J.P. 2006. Monitoring predator-prey interactions using multiple predator species: the South Georgia experience. In Boyd, I.L. Wanless, S. \& CAmphuysen, C.J., eds. Top predators in marine ecosystems. Cambridge: Cambridge University Press, 157-176.

Cury, P.M., Boyd, I.L., Bonhommeau, S., Anker-Nilssen, T., Crawford, R.J., Furness, R.W. \& Sydeman, W.J. 2011. Global seabird response to forage fish depletion - one third for the birds. Science, 334, 1703-1706.

Daily, G.C., Polasky, S., Goldstein, J., Kareiva, P.M., Mooney, H.M., Pejchar, L., Ricketts, T.H., Salzman, J. \& Shallenberger, R. 2009. Ecosystem services in decision making: time to deliver. Frontiers in Ecology and the Environment, 7, 21-28.

Dasgupta, P. 2010. Nature's role in sustaining economic development. Philosophical Transactions of the Royal Society, B365, 5-11.

Everson, I., Stonehouse, B., Drewry, D.J. \& Barker, P.F. 1992. Managing Southern Ocean krill and fish stocks in a changing environment. Philosophical Transactions of the Royal Society of London, B338, 311-317.

FAO (Food and Agriculture Organization). 2012. The state of world fisheries and aquaculture. Part 1. World review of fisheries and aquaculture. Rome: Food and Agriculture Organization of the United Nations, 84 pp.

Field, C.B., Behrenfeld, M.J., Randerson, J.T. \& Falkowski, P. 1998. Primary production of the biosphere: integrating terrestrial and oceanic components. Science, 281, 237-240.

Fisher, B., Turner, R.K. \& Morling, P. 2009. Defining and classifying ecosystem services for decision making. Ecological Economics, 68, 643-653. 
Flores, H., Atrinson, A., Kawagushi, S., Krafft, B.A., Milinevsky, G., Nicol, S., Reiss, C., Tarling, G.A., Werner, R., Bravo Rebolledo, E., Cirelli, V., Cuzin-Roudy, J., Fielding, S., Groeneveld, J., Haraldsson, M., Lombana, A., Marschoff, E., Meyer, B., Pakhomov, E.A., Rombolá, E., Schmidt, K., Siegel, V., Teschke, M., Tonkes, H., Toullec, J., Trathan, P., Tremblay, N., van de Putte, A., van Franeker, J.A. \& WERNER, T. 2012. Impact of climate change on Antarctic krill. Marine Ecology-Progress Series, 458, 1-19.

Forcada, J. \& Trathan, P.N. 2009. Penguin responses to climate change in the Southern Ocean. Global Change Biology, 15, 1618-1630.

Forcada, J., Trathan, P.N., Reid, K. \& Murphy, E.J. 2005. The effects of global climate variability in pup production of Antarctic fur seals. Ecology, 86, 2408-2417.

Garcia, S.M. \& Rosenburg, A.A. 2010. Food security and marine capture fisheries: characteristics, trends, drivers and future perspectives. Philosophical Transactions of the Royal Society of London, B256, 2869-2880.

GiLPIN, A. 2000. Environmental economics: a critical overview. New York: Wiley, 352 pp.

Hanchet, S.M., Rickard, G.J., Fenaughty, J.M., Dunn, A. \& Williams, M.J. 2008. A hypothetical life cycle for Antarctic toothfish (Dissostichus mawsoni) in the Ross Sea region. CCAMLR Science, 15, 35-53.

Headland, R.K. 1992. The island of South Georgia. Cambridge: Cambridge University Press, 294 pp.

Hewitt, R.P., Watters, G., Trathan, P.N., Croxall, J.P., Goebel, M., Ramm, D., Reid, K., Trivelpiece, W.Z. \& Watkins, J.L. 2004b. Options for allocating the precautionary catch limit of krill among small-scale management units in the Scotia Sea. CCAMLR Science, 11, 81-97.

Hewitt, R.P., Watkins, J., Naganobu, M., Sushin, V., Brierley, A.S., Demer, D., Kasatkina, S., Takao, Y., Goss, C., Malyshko, A., Brandon, M., Kawaguchi, S., Siegel, V., Trathan, P., Emery, J., Everson, I. \& Miller, D. 2004a. Biomass of Antarctic krill in the Scotia Sea in January/February 2000 and its use in revising an estimate of precautionary yield. Deep-Sea Research Part II, 51, 1215-1236.

HILL, S.L. 2013a. Prospects for a sustainable increase in the availability of long chain omega 3s: lessons from the Antarctic krill fishery. In De Meester, F., Watson, R.R. \& ZiBadi, S., eds. Omega 6/3 fatty acids functions, sustainability strategies and perspectives. New York: Humana Press, 267-296.

HILL, S.L. 2013b. From strategic ambiguity to technical reference points in the Antarctic krill fishery: the worst journey in the world? Environmental Conservation, 10.1017/S0376892913000088.

Hill, S.L., Forcada, J., Trathan, P.N. \& Waluda, C.M. 2010. Using ecosystem monitoring data to detect impacts. CCAMLR Science, 17, 197-212.

Hill, S.L., Keeble, K., Atkinson, A. \& Murphy, E.J. 2012. A foodweb model to explore uncertainties in the South Georgia shelf pelagic ecosystem. Deep Sea Research Part II, 59, 237-252.

Hill, S.L., Murphy, E.J., Reid, K., Trathan, P.N. \& Constable, A.J. 2006. Modelling Southern Ocean ecosystems: krill, the food-web, and the impacts of fishing. Biological Reviews, 81, 581-608.

IPBES (Intergovernmental platform on biodiversity and ecosystem services). 2012. Catalogue of assessments. Intergovernmental platform on biodiversity and ecosystem services. http://ipbes.unepwcmc004.vm.brightbox.net/, accessed April 2013.

JABour-Green, J. \& Nicol, D. 2003. Bioprospecting in areas outside national jurisdiction: Antarctica and the Southern Ocean. Melbourne Journal of International Law, 4, 76-112.

Jacquet, J.D., Pauly, D., Ainley, D., Dayton, P., Holt, S. \& Jackson, J. 2010. Seafood stewardship in crisis. Nature, 467, 28-29.

Kock, K.-H. 1992. Antarctic fish and fisheries. Cambridge: Cambridge University Press, 375 pp.

Knox, G.A. 2007. Biology of the Southern Ocean. 2nd ed. Boca Raton, FL: CRC Press, 640 pp.

Laws, R.M. 1953. The elephant seal industry at South Georgia. Polar Record, 6, 746-754.
Ledoux, L. \& TuRner, R.K. 2002. Valuing ocean and coastal resources: a review of practical examples and issues for further action. Ocean and Coastal Management, 45, 583-616.

Le Quéré, C., Rödenbeck, C., Buitenhuis, E.T., Conway, T.J., Langenfelds, R., Gomez, A., Labuschagne, C., Ramonet, M., Nakazawa, T., Metzl, N., Gillett, N. \& Heimann, M. 2007. Saturation of the Southern Ocean $\mathrm{CO}_{2}$ sink due to recent climate change. Science, 316, 1735-1738.

LinK, J.S. 2010. Ecosystem-based fisheries management. Cambridge, UK: Cambridge University Press, $224 \mathrm{pp}$.

Loeb, V., Siegel, V., Holm-Hansen, O., Hewitt, R., Fraser, W., Trivelplece, W. \& Trivelplece, S. 1997. Effects of sea ice extent and krill or salp dominance on the Antarctic food web. Nature, 387, 897-900.

Lumpkin, R. \& SPEeR, K. 2007. Global ocean meridional overturning. Journal of Physical Oceanography, 37, 2250-2562.

Lynch, H.J., Crosbie, K., Fagan, W.F. \& NaveEn, R. 2010. Spatial patterns of tour ship traffic in the Antarctic Peninsula region. Antarctic Science, 22, 123-130.

Maes, J., Braat, L., Jax, K., Hutchins, M., Furman, E., Termansen, M., Luque, S., Paracchini, M.L., Chauvin, C., Williams, R., Volk, M., Lautenbach, S., Kopperoinen, L., Schelhaas, M-J., Weinert, J., Goosen, M., Dumont, E., Strauch, M., Gorg, C., Dormann, C., Katwinkel, M., Zulian, G., Varjopuro, R., Ratamaki, O., Hauck, J., Forsius, M., Hengeveld, G., Perez-Soba, M., Bouraoui, F., Scholz, M., Schulz-Zunkel, C., Lepisto, A., Polishchuck, Y. \& Bidoglio, G. 2011. A spatial assessment of ecosystem services in Europe: methods, case studies and policy analysis - phase 1. PEER Report, No. 3. Ispra: Partnership for European Environmental Research, 148 pp.

Mayewski, P.A., Meredith, M.P., Summerhayes, C.P., Turner, J., Worby, A., Barrett, J., Casassa, G., Bertler, N.A.N., Bracegirdle, T., Naveira Garabato, A.C., Bromwich, D., Campbell, H., Hamilton, G.S., Lyons, W.B., MaAsch, K.A., Aoki, S., XiaO, S. \& van Ommen, T. 2009. State of the Antarctic and Southern Ocean climate system. Reviews of Geophysics, 10.1029/2007RG00231.

McLeOD, K.L. \& LesLIE, H.M. 2009. Why ecosystem-based management?. In McLeod, K. \& LesLie, H., eds. Ecosystem-based management for the oceans. Washington DC: Island Press, 3-12.

Millennium Ecosystem Assessment. 2005. Ecosystems and human wellbeing: current states and trends. Washington DC: Island Press, 948 pp.

Miller, D. \& Agnew, D. 2000. Management of krill fisheries in the Southern Ocean. In Everson, I., ed. Krill biology, ecology and fisheries. Oxford: Blackwell, 300-337.

Moore, J., Авbott, M. \& Richman, J. 1997. Variability in the location of the Antarctic Polar Front $\left(90^{\circ}-20^{\circ} \mathrm{W}\right)$ from satellite sea surface temperature data. Journal of Geophysical Research, 102, $27825-27833$.

Murphy, E.J., Cavanagh, R.D., Hofmann, E.E., Hill, S.L., Constable, A.J., CostA, D.P. \& Doney, S.C. 2012. Developing integrated models of Southern Ocean food webs: including ecological complexity, accounting for uncertainty and the importance of scale. Progress in Oceanography, 102, 74-92.

Naidoo, R., Balmford, A., Costanza, R., Fisher, B., Green, R.E., Lehner, B., Malcolm, T.R. \& RicketTs, T.H. 2008. Global mapping of ecosystem services and conservation priorities. Proceedings of the National Acadamey of Science of the United States of America, 105, 9495-9500.

Nicol, S., Foster, J. \& Kawaguchi, S. 2012. The fishery for Antarctic krill - recent developments. Fish and Fisheries, 13, 30-40.

Orsi, A.H., JACobs, S.S., Gordon, A.L. \& VisBeCK, M. 2001. Cooling and ventilating the abyssal ocean. Geophysical Research Letters, 28, 2923-2926.

Österblom, H. \& Bodin, Ö. 2012. Global cooperation among diverse organizations to reduce illegal fishing in the Southern Ocean. Conservation Biology, 26, 638-648. 
Pikitch, E.K., Rountos, K.J., Essington, T.E., Santora, C., Pauly, D., Watson, R., Sumaila, U.R., Boersma, P.D., Boyd, I.L., Conover, D.O., Cury, P., Heppell, S.S., Houde, E.D., Mangel, M., Plagányi, É., Sainsbury, K., Steneck, R.S., Geers, T.M., Gownaris, N. \& Munch, S.B. 2012. The global contribution of forage fish to marine fisheries and ecosystems. Fish \& Fisheries, 10.1111/faf.12004.

Plagányi, É.E. \& Butterworth, D.S. 2012. The Scotia Sea krill fishery and its possible impacts on dependent predators: modeling localized depletion of prey. Ecological Applications, 22, 748-761.

Priddle, J., Boyd, I.L., Whitehouse, M.J., Murphy, E.J. \& Croxall, J.P. 1998. Estimates of Southern Ocean primary production - constraints from predator carbon demand and nutrient drawdown. Journal of Marine Systems, 17, 275-288.

Sabine, C.L., Feely, R.A., Gruber, N., Key, R.M., Lee, K., Bullister, J.L., Wanninkhof, R., Wong, C.S., Wallace, D.W.R., Tilbrook, B., Millero, F.J., Peng, T.H., Kozyr, A., Ono, T. \& Rios, A.F. 2004. The oceanic sink for anthropogenic $\mathrm{CO}_{2}$. Science, 305, 367-371.

SAunders, J., Tinch, R. \& HulL, S. 2010. Valuing the marine estate and UK seas: an ecosystem services framework. The Crown Estate, $54 \mathrm{pp}$.

SC-CAMLR. 1994. Report of the Eighth Meeting of the Scientific Committee. Hobart, TAS: CCAMLR, 444 pp.

SC-CAMLR. 2010. Report of the Twenty-ninth Meeting of the Scientific Committee. Hobart, TAS: CCAMLR, $426 \mathrm{pp}$.

SC-CAMLR. 2011. Report of the Thirtieth Meeting of the Scientific Committee. Hobart, TAS: CCAMLR, $460 \mathrm{pp}$.

SC-CAMLR. 2012. Report of the Thirty-first Meeting of the Scientific Committee. Hobart, TAS: CCAMLR, 105 pp.

Smith, A.D., Brown, C.J., Bulman, C.M., Fulton, E.A., Johnson, P., Kaplan, I.C., Lozano-Montes, H., Mackinson, S., Marzloff, M., Shannon, L.J., Shin, Y.J. \& TAM, J. 2011. Impacts of fishing low-trophic level species on marine ecosystems. Science, 333, 1147-1150.

TEEB. 2010. The economics of ecosystems and biodiversity. Mainstreaming the economics of nature: a synthesis of the approach, conclusions and recommendations of TEEB. http://www.teebweb.org/ wp-content/uploads/Study\%20and\%20Reports/Reports/Synthesis\%20report/ TEEB\%20Synthesis\%20Report\%202010.pdf, 39 pp.

Tin, T., Fleming, Z.L., Hughes, K.A., Ainley, D.G., Convey, P., Moreno, C.A. \& Pfeiffer, S. 2009. Impacts of local human activities on the Antarctic environment. Antarctic Science, 21, 3-33.

Tréguer, P. \& JACQUES, G. 1992. Dynamics of nutrients and phytoplankton, and fluxes of carbon, nitrogen and silicon in the Southern Ocean. Polar Biology, 12, 149-162.
Trathan, P.N. \& Agnew, D. 2010. Climate change and the Antarctic marine ecosystem: an essay on management implications. Antarctic Science, 22, 387-398.

Trathan, P.N. \& Reid, K. 2009. Exploitation of the marine ecosystem in the sub-Antarctic: historical impacts and current consequences. Papers and Proceeding of the Royal Society of Tasmania, 143, 9-14.

Trathan, P.N., Ratcliffe, N. \& Masden, E.A. 2012. Ecological drivers of change at South Georgia: the krill surplus, or climate variability. Ecography, 35, 983-993.

Trathan, P.N., Everson, I., Miller, D.G.M., Watkins, J.L. \& Murphy, E.J. 1995. Krill biomass in the Atlantic. Nature, 373, 201-202.

Turner, J. \& Overland, J. 2009. Contrasting climate change in the two polar regions. Polar Research, 28, 146-164.

Turner, J., Bindschadler, R., Convey, P., Di Prisco, G., Fahrbach, E., Gutt, J., Hodgson, D.A., Mayewski, P.A. \& Summerhayes, C.P. eds., 2009. Antarctic climate change and the environment. Cambridge: Scientific Committee for Antarctic Research (SCAR), 554 pp.

UK NEA 2011. The UK National Ecosystem Assessment: synthesis of the key findings. Cambridge: UNEP-WCMC, 87 pp.

UNEP (United Nations Environment Programme). 2010. Global synthesis. A report from the Regional Seas Conventions and action plans for the Marine Biodiversity Assessment and Outlook Series. United Nations Environment Programme: Regional Seas Programme, http:// marinebiodiversityseries.org/reports/UNEP\%20Global\%20Synthesis\% 20Marine\%20Biodiversity\%20Series.pdf, 58 pp.

UNEP (United Nations Environment Programme). 2012. GEO5 Global environmental outlook. United Nations Environment Programme, $550 \mathrm{pp}$.

Watters, G.M., Hill, S.L., Hinke, J., Matthews, J. \& Reid, K. In press. Decision making for ecosystem based management: evaluating options for a krill fishery with an ecosystem dynamics model. Ecological Applications.

Worm, B., Hilborn, R., Baum, J.K., Branch, T.A., Collie, J.S., Costello, C., Fogarty, M.J., Fulton, E.A., Hutchings, J.A., Jennings, S., Jensen, O.P., Lotze, H.K., Mace, P.A., McClanahan, T.R., Minto, C., Palumbi, S.R., Parma, A.M., Ricard, D., Rosenberg, A.A., Watson, R. \& Zeller, D. 2009. Rebuilding global fisheries. Science, 325, 578-585.

ZACHARIAS, M.A. \& RofF, J.C. 2001. Use of focal species in marine conservation and management: a review and critique. Aquatic Conservation: Marine \& Freshwater Ecosystems, 11, 59-76. 